\title{
SPARCL1 Gene
}

National Cancer Institute

\section{Source}

National Cancer Institute. SPARCL1 Gene. NCI Thesaurus. Code C106064.

This gene may be involved in leukocyte transendothelial migration. 